\title{
CORRECTION
}

View Article Online

View Journal I View Issue

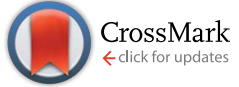

Cite this: RSC Adv., 2015, 5, 74539

DOI: $10.1039 / c 5 r a 90081 f$

www.rsc.org/advances

\section{Correction: Selective detection of fluoride using fused quinoline systems: effect of pyrrole}

\author{
Mahesh Akula, Yadagiri Thigulla, Amit Nag and Anupam Bhattacharya*
}

Correction for 'Selective detection of fluoride using fused quinoline systems: effect of pyrrole' by Mahesh Akula et al., RSC Adv., 2015, 5, 57231-57234.

The authors would like to correct some errors present in the original article.

In page 57232, in the third paragraph of the right column, the sentence "In cases of ligands 7 and $\mathbf{8}$, pyrrole $\mathrm{NH}$ and hydroxyl were blocked, respectively" should read: "In cases of ligands $\mathbf{8}$ and $\mathbf{9}$, pyrrole NH and hydroxyl were blocked, respectively".

In addition, some of the structures in Table 1 were not displayed correctly (ligands $\mathbf{6 , 9}$ and 13). The corrected Table 1 is shown below.

Table 1 Study of selective fluoride sensing with various ligands

Ligand


Table 1 (Contd.)

Ligand

8

9

10

11

12<smiles>COc1ccccc1-c1nc2ccccc2c2cc[nH]c12</smiles><smiles>Oc1cccc(-c2nc3ccccc3c3cc[nH]c23)c1</smiles><smiles>Oc1ccc(-c2nc3ccccc3c3[nH]ccc23)cc1</smiles><smiles></smiles>

13<smiles>Oc1ccc2ccccc2c1-c1nc2ccccc2c2cc[nH]c12</smiles><smiles>O=c1ccc2ccc(O)c(-c3nc4ccccc4c4cc[nH]c34)c2o1</smiles>

14<smiles>Oc1ccccc1-c1nc2ccccc2c2ocnc12</smiles>

No selectivity

No selectivity

No selectivity

No selectivity

$\mathrm{F}^{-}$selective $^{b}$

$\mathrm{F}^{-}$selective

$\mathrm{F}^{-}$selective

$\mathrm{F}^{-}$selective

${ }^{a}$ Ligands showing selective $\mathrm{F}^{-}$sensing also show $\mathrm{AcO}^{-}$sensing, which can be easily removed by using TBDPS protection of hydroxyl group. ${ }^{b}$ No red shift and no $\mathrm{AcO}^{-}$interference.

The Royal Society of Chemistry apologises for these errors and any consequent inconvenience to authors and readers. 